\title{
An Insight towards Trends and Effectiveness of Vertical Handoff Mechanism
}

\author{
Hemavathi \\ Research Scholar \\ Dept. of ECE, BMSCE, Bangalore, India
}

\author{
S. Akhila \\ Prof., Dept. of ECE \\ BMSCE, Bangalore, India
}

\begin{abstract}
With increasing technological advancement of mobile computing and mobile networks, there is an increasing concern about a sustainable vertical handoff mechanism for large scale heterogeneous networks. In existing communication technology, different types of networking protocols often pose a challenge in rendering an effective communication when the mobile user moves from one to other forms of wireless networks (3G, 4G, WiMax, GPRS, CDMA, WLAN, etc). One of the significant factors to ensure an effective handoff mechanism is ensure a faster authentication process handling all the complexities of heterogeneous network. Hence, this paper discusses about the significant research attempts being done to enhance the vertical handoff performance with respect to handling complexities of heterogeneity, ensuring faster authentication process. The paper also discusses the existing literatures towards study of WLAN and CDMA network and finally the paper discusses about the significant research gaps identified by in-depth analysis of the outcomes of the existing literatures.
\end{abstract}

\section{Keywords}

Handoff, vertical handoff, heterogeneous network, WLAN-3G

\section{INTRODUCTION}

With the increasing demands of the pervasiveness and data availability, there has been a lot of revolution changes in the cellular communication technology witnessed most recently. As cellular system offers infrastructure-dependent connectivity, it is very important that there should be seamless connectivity among the existing mobile user [1]. At present, there are various types of communication technologies e.g. UMTS, GPRS, 2G, 3G, 4G, WLAN, WiMax, CDMA etc. All these networking technologies differ from each other in their respective protocol stacks [2]. Owing to such differences in the communication protocols, it leads to various problems e.g. i) increased capacity for connecting new calls, ii) change of user behavior, iii) channel interference, iv) unanticipated call termination, v) outage etc. Therefore, in order to avoid all these mentioned problems, it is essential that handoff mechanism be performed for controlling such networking and connectivity pitfalls. An efficient handoff mechanism leads to enhanced reception with less probability of call drop and also design and implementation of precise handoff mechanism will lead to better load-balancing algorithm for properly managing the multiple resources in the cellular network [3][4][5]. Such principles of handoff mechanism is also strengthened by incorporating handoff prioritization techniques [6][7]. The existing handoff algorithm always attempts to minimize the frequency of handoff event, which is quite detrimental for optimal communication performance in large traffic situation. Hence, handoff prioritization can be done using guard channel method and queuing method [8]. The first technique reserves a constant or changing number of channels required for handoff, while the second technique is used for balancing the load.

In existing system, there are 4 types of standard protocols that is used for performing handoff mechanism viz. i) Mobileassisted handoff [9], ii) Network-controlled handoff [10], iii) Soft and hard handoff [11], and iv) Mobile-Controlled handoff [12]. Essentially, the handoff scheme has been also reviewed with respect to 5 different schemes e.g. i) priority scheme, i) handoff calls, iii) non-priority scheme, iv) queuing scheme, and v) handoff call queuing scheme [13]. With the upcoming technological requirements in $4 \mathrm{G}$, Internet-ofThings, Cloud Computing etc, it is important that handoff mechanism be thoroughly investigated. Our prior work [14] a Survey on Delay in Vertical Handoff in Heterogeneous Wireless Networks has reviewed mainly the delay factor in vertical handoff by discussing the work towards probe delay, authentication delay, decision delay, re-association delay. The paper also discussed certain open issues; however, authors strongly felt that there is a need to put forward some more updated work in this regards. Hence investigations are continued to find that there are also some significant studies towards heterogeneity factor, authentication factor, and WLAN-CDMA network. The paper [14] lacks the scope of discussion of research gap in descriptive manner as well as indepth analysis of the existing research contribution. Hence, this paper fulfills this need by performing an in-depth review of literature towards the existing techniques of vertical handoff mechanism and also significantly discusses about the research gap being explored from the study. Section 2 discusses about the brief fundamentals of handoff and highlights the technical requirements for carrying out vertical handoff schemes. Section 3 discusses about the most significant literatures focusing on enhancing the performance of heterogeneous network when vertical handoff takes place. Section 4 discusses about the studies being considering the authentication mechanism involved in vertical handoff process. Section 5 discusses about the significant attempts of researchers exclusively towards WLAN and CDMA. Finally Section 6 highlights the research gap identified after in-depth analysis of the literatures and Section 7 summarizes the manuscript.

\section{STUDIES TOWARDS HANDOFF}

The handoff can be said to be performed when a user gets the connectivity of their data even when they are moving from one to different networking area [15]. In telecommunications handoff might be conducted due to different reasons:

- When the Mobile station moves away from one cell to another,

- When a new call is originating from a Mobile station belonging to a cell, whose new calls connecting capacity 
is used up. Then this call is transferred to the cell which is overlapped on this.

- When the same channel is accessed by the two Mobile stations belonging to different cells then the channel gets interfered, the call is transferred to a different channel in the same cell or different channel in another cell in order to avoid the interference.

- When received signal level values and received signal quality values are low on the serving cell and better on the neighbor cell; etc.

Generally, handoff is of two types i) horizontal handoff and ii) vertical handoff [15]. A horizontal handoff occurs between two network access points that use the same network technology and interface. A vertical handoff is a mechanism to perform handoff operation between the two different types of network access point by deploying different networking technologies [16]. The schema of horizontal and vertical handoff is shown in Fig.1

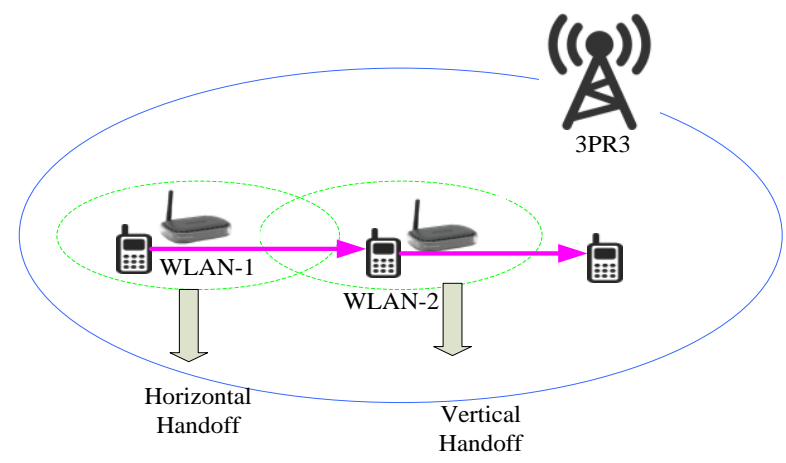

Fig 1: Schema of Vertical handoff

Majority of the method adopted to perform handoff are categorized to hard and soft handoff [15].

Before, starting to review the existing literatures on vertical handoff mechanism it is important to understand the factors to be considered for implementing a handoff mechanism over the heterogeneous network, which are as follows:

- $\quad$ There should be a reduced number of handoff events as more number of handoff events often results in degradation of quality of signal with maximized probability of packet dropping factor, also results in additional load on the traffic; hence, it should be kept as low as possible.

- The handoff should be accomplished in the shortest duration of time (low delay).
- The handoff mechanism should offer reliable and secure data transmission with seamless connectivity over heterogeneous networks.

- In case of heavy traffic on WLAN, it often results in data overflow. Hence, performing handoff mechanism over such WLAN traffic should be avoided etc.

\section{STUDIES TOWARDS \\ HETEROGENEOUS NETWORK}

Heterogeneous network refers to wireless networks that are using different access technologies. The type of handoff that takes place in heterogeneous network is vertical handoff. At present, the existing specifications (fixed IPv6) of the internet protocol are found not to support vertical handoff. As IP in existing internet protocol is the universal standard, hence, all the entities beyond it will be abstracted from the communication-based application. Hence, in order to support IPv6, a background process is required to be designed and to be executed in the network layer that performs switching among the heterogeneous networking protocols. The background process in the network is then used to select the specific network depending on the speed of the active networks, utility cost, Quality-of-Service etc. However, such selection of the network is highly customizable as well as necessary changes in the protocol stack can be done based on the application requirements. Once the network is selected, the handoff mechanism encapsulates the IP datagram in the precise versions of radio access operation to be used.

In case of vertical handoff mechanism, adoption of WLAN is found to be very frequent. In the area of vertical handoff, it was also found that decisions were formulated by comparing the signal strength of the existing network with certain significant benchmarked value, which is also called as threshold. However, such techniques are not that complex and are feasible to get it integrated with other attributes e.g. channel capacity, cost etc in order to formulate better handoff decision. Some of the techniques based on signal strength are i) Adaptive lifetime based vertical handoff mechanism presented by Zahran et al. [17], ii) adaptive threshold based schemes presented by Mohanty [18], distance based prediction techniques presented by Yan et al. [19]. It is significant to consider these studies as signal strength, handoff delay, and security are some of the significant network parameters in study of vertical handoff mechanism. The vertical handoff mechanism is ensured by performing i) collection of handoff information, ii) decision for handoff, and iii) execution of handoff. The effectiveness factor depends on quantity of successful handoff with respect to cumulative handoff being made. Table 1 highlights some of the significant research attempts being made towards vertical handoff in heterogeneous network.

Table.1: Summary of Studies on Vertical Handoff in Heterogeneous Network

\begin{tabular}{|l|l|l|l|l|}
\hline \multicolumn{1}{|c|}{ Authors } & Handoff Problem & Techniques Adopted & $\begin{array}{c}\text { Performance } \\
\text { Parameters }\end{array}$ & \multicolumn{1}{|c|}{ Inference } \\
\hline $\begin{array}{l}\text { Choi and Cho } \\
{[20]}\end{array}$ & $\begin{array}{l}\text { Next generation } \\
\text { network and its } \\
\text { Seamless mobility }\end{array}$ & $\begin{array}{l}\text { Request processing for } \\
\text { mobile nodes by neighbor } \\
\text { nodes }\end{array}$ & $\begin{array}{l}\text { Speed of mobile node, } \\
\text { handoff probability, } \\
\text { Dropped packets, } \\
\text { energy }\end{array}$ & $\begin{array}{l}\checkmark \text { faster handoff } \\
\times \text { Outcomes not benchmarked }\end{array}$ \\
\hline $\begin{array}{l}\text { Zahran et al. } \\
{[21]}\end{array}$ & $\begin{array}{l}\text { 3G cellular and } \\
\text { WLAN }\end{array}$ & $\begin{array}{l}\text { Threshold scheme based } \\
\text { on signal threshold }\end{array}$ & $\begin{array}{l}\text { Speed, no. of handoffs, } \\
\text { bandwidth, delay, }\end{array}$ & $\begin{array}{l}\checkmark \text { Enhances utilization of system } \\
\text { resources }\end{array}$ \\
\hline
\end{tabular}




\begin{tabular}{|c|c|c|c|c|}
\hline & & & & $\begin{array}{ll}x \text { Outcomes } & \text { not benchmarked, } \\
\text { Algorithm } & \text { complexity not } \\
\text { discussed. } & \end{array}$ \\
\hline Liu et al. [22] & Decision problem & $\begin{array}{l}\text { hysteresis based } \\
\text { technique, dwelling-timer } \\
\text { based algorithms }\end{array}$ & $\begin{array}{l}\text { Handoff triggering } \\
\text { location }\end{array}$ & $\begin{array}{l}\checkmark \text { Theoretically studied on GPRS } \\
\text { and Wi-Fi } \\
\times \text { Issues of ping-pong effect and } \\
\text { reduction of matching ratio not } \\
\text { discussed. }\end{array}$ \\
\hline $\begin{array}{l}\text { Navarro et al. } \\
{[23]}\end{array}$ & Decision problem & $\begin{array}{l}\text { Algorithm based on state } \\
\text { space, reward function, } \\
\text { and transition feasibility }\end{array}$ & $\begin{array}{l}\text { Reward, switching cost, } \\
\text { no. of handoff, weight } \\
\text { factor }\end{array}$ & $\begin{array}{l}\checkmark \quad \text { optimal decision for } \\
\text { heterogeneous network } \\
\text { xless focus on authentication } \\
\text { delays. }\end{array}$ \\
\hline $\begin{array}{l}\text { Arun and } \\
\text { Moni [24] }\end{array}$ & $\begin{array}{l}\text { QoS provision over } \\
4 \mathrm{G}\end{array}$ & $\begin{array}{l}\text { Developed power } \\
\text { management techniques }\end{array}$ & $\begin{array}{l}\text { Throughput, channel } \\
\text { occupancy }\end{array}$ & $\begin{array}{l}\text { dynamic and self-adaptable } \\
\text { algorithm } \\
\times \text { Outcomes not benchmarked less } \\
\text { focus on authentication scheme. }\end{array}$ \\
\hline $\begin{array}{l}\text { Gondara and } \\
\text { Kadam [25] }\end{array}$ & $\begin{array}{l}\text { Vertical handoff in } \\
4 \mathrm{G}\end{array}$ & $\begin{array}{l}\text { Analyzed and studied } \\
\text { existing techniques }\end{array}$ & $-\mathrm{N} / \mathrm{A}$ & $\begin{array}{l}\checkmark \text { Discussion paper } \\
\times \text { No discussion of research gap }\end{array}$ \\
\hline $\begin{array}{l}\text { Sharna \& } \\
\text { Murshed [26] }\end{array}$ & Decision problem & Markov decision & $\begin{array}{l}\text { Bandwidth, no. of } \\
\text { handoff, switching cost, } \\
\text { weight, discount factor }\end{array}$ & $\begin{array}{l}\checkmark \text { Achieved higher bandwidth } \\
\times \text { less focus on authentication } \\
\text { delays }\end{array}$ \\
\hline $\begin{array}{l}\text { Bijwe \& Dethe } \\
\text { [27] }\end{array}$ & RSS & $\begin{array}{l}\text { Discussed RSS based } \\
\text { vertical handoff }\end{array}$ & $-\mathrm{N} / \mathrm{A}$ & $\begin{array}{l}\checkmark \text { Discussion paper } \\
\times \text { No discussion of research gap. }\end{array}$ \\
\hline $\begin{array}{l}\text { Nithyanandan } \\
\& \quad \text { Parthiban } \\
{[28]}\end{array}$ & WLAN-WiMax-LTE & $\begin{array}{ll}\begin{array}{l}\text { Gateway } \\
\text { process }\end{array} & \text { relocation } \\
\end{array}$ & $\begin{array}{l}\text { Power, delay, } \begin{array}{r}\text { SNR, } \\
\text { packets } \\
\text { velocity, }\end{array} \\
\text { dropped, }\end{array}$ & $\begin{array}{l}\checkmark \text { better coupling techniques } \\
\times \text { Outcomes not benchmarked, } \\
\text { probe-based delay not discussed. }\end{array}$ \\
\hline $\begin{array}{ll}\text { Kadhim } & \& \\
\text { Abed [29] } & \end{array}$ & $\begin{array}{l}\text { WLAN \& Cellular } \\
\text { network }\end{array}$ & Hybrid Algorithm & No. of handoff, velocity, & $\begin{array}{l}\checkmark \text { reduction in handoff } \\
\times \text { Algorithm complexity not } \\
\text { discussed less extensive discussion. }\end{array}$ \\
\hline Kunarak [30] & $\begin{array}{l}\text { UMTS- } \\
\text { WLAN/WiMax }\end{array}$ & Neural network & $\begin{array}{l}\text { RSS, distance, velocity, } \\
\text { dropping probability, } \\
\text { call arrival rate, grade of } \\
\text { services }\end{array}$ & $\begin{array}{l}\checkmark \text { Flexible handoff policy } \\
\times \text { Authentication delay not } \\
\text { discussed. }\end{array}$ \\
\hline Shen et al. [31] & $\begin{array}{l}\text { Selection of good } \\
\text { QoS network }\end{array}$ & $\begin{array}{l}\text { Principle } \\
\text { Analysis }\end{array}$ & $\begin{array}{l}\text { Time, principle } \\
\text { components }\end{array}$ & $\begin{array}{l}\checkmark \text { Enhances system performance } \\
\times \text { Authentication delay not } \\
\text { discussed, algorithm complexity } \\
\text { not analyzed. }\end{array}$ \\
\hline
\end{tabular}

\section{STUDIES TOWARDS AUTHENTICATION MECHANISM}

Providing seamless vertical handoff calls for faster deployment of authentication process and it is quite important that mobile terminals to be appended with multiple base stations or the access points in heterogeneous networks. However, it is not that easy. In order to ensure the availability of the services to mobile terminal, it is equally important to conglomerate an efficient security standards, services offered by service providers, and operators. Apart from security based authentication system in vertical handoff in heterogeneous network, various forms of services should be interoperable for providing an effective mobility trait with existing wireless standards. In the case of $3 \mathrm{G}$, the authentication purely depends on updating process of routing area. In case of $3 \mathrm{GPP}$, the authentication process depends on the key agreement and cryptographic techniques. In case of WLAN, the authentication process is again different. WLAN uses an Extensible Authentication Protocol with Tunneled Transport Layer security. Literatures have also found that probing phase and re-association phase are the prime factors responsible behind authentication delay in WLAN. Wherever a vertical handoff takes place, for the purpose of security, an authentication process should be performed to verify the identity of the mobile terminal. In the wireless services, secure and secret communication is desirable. If the authentication is successful, then the encryption of data and signaling is targeted. However, such types of existing authentication schemes are associated with the pitfalls 
pertaining to the mobility. Such authentication schemes are found to consume considerable processing time as well as mechanism of authentication is not found much efficient owing to the frequent round trip as needed from one terminal of service provider to the consumer's domain. Therefore, there is a need of fast as well as efficient authentication policy that uses authentication server located near the mobile customer. Table 2 highlights summary of studies on Fast Authentication Protocols in Vertical Handoff.

\section{Table 2: Summary of Studies on Fast Authentication Protocols in Vertical Handoff}

\begin{tabular}{|c|c|c|c|c|}
\hline Authors & Techniques Adopted & $\begin{array}{l}\text { Performance } \\
\text { Parameters }\end{array}$ & Accomplishment & Limitation \\
\hline $\begin{array}{l}\text { Huang et al. } \\
{[32]}\end{array}$ & $\begin{array}{l}\text { 3G-WLAN- } \\
\text { cryptographic key } \\
\text { management }\end{array}$ & $\begin{array}{l}\text { Delay, time, overhead of } \\
\text { key distribution }\end{array}$ & $\begin{array}{l}\checkmark 10 \text { seconds of delay } \\
\text { accomplished }\end{array}$ & $\begin{array}{l}x \text { Key management could be } \\
\text { further enhanced; resource access } \\
\text { controls have more scope to be } \\
\text { upgraded. }\end{array}$ \\
\hline \begin{tabular}{lll|} 
Dutta & et & al. \\
{$[33]$} & &
\end{tabular} & $\begin{array}{l}\text { Framework for } \\
\text { Handoff optimization }\end{array}$ & $\begin{array}{l}\text { Mobility rate, packet loss, } \\
\text { jitter, buffering period }\end{array}$ & $\begin{array}{l}\quad \text { Reduces delay of } \\
\text { inter-domain handoff }\end{array}$ & $\begin{array}{l}\text { xAlgorithm complexity is not } \\
\text { discussed. }\end{array}$ \\
\hline $\begin{array}{l}\text { Murtaza \& } \\
\text { Ahmed [34] }\end{array}$ & $\begin{array}{l}\text { 3G-WLAN-adaptive } \\
\text { and predictive } \\
\text { scheme of network } \\
\text { selection }\end{array}$ & $\begin{array}{l}\text { Latency, interference, } \\
\text { velocity, bandwidth, } \\
\text { packet error rate, energy }\end{array}$ & $\begin{array}{l}\quad \text { Ensures reduced } \\
\text { latency and zero loss of } \\
\text { packet }\end{array}$ & $\begin{array}{l}x \text { less consideration of energy of } \\
\text { mobile nodes. }\end{array}$ \\
\hline $\begin{array}{l}\text { Zahran and } \\
\text { Sreenan [35] }\end{array}$ & $\begin{array}{l}\text { Broker-based schema } \\
\text { for heterogeneous } \\
\text { network }\end{array}$ & $\begin{array}{l}\text { Delay, interruption, } \\
\text { probability, }\end{array}$ & 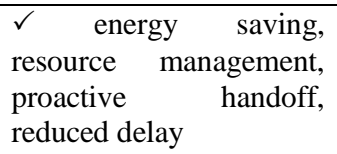 & $\times$ Authentication is less secured. \\
\hline $\begin{array}{l}\text { Faisal \& Khan } \\
\text { [36] }\end{array}$ & $\begin{array}{l}\text { Reactive and } \\
\text { proactive Scheme }\end{array}$ & Delay & $\begin{array}{l}\checkmark \text { A simple technique to } \\
\text { reduce delay }\end{array}$ & $\begin{array}{l}\times \text { Address acquisition problems not } \\
\text { discussed, outcomes not discussed } \\
\text { extensively. }\end{array}$ \\
\hline $\begin{array}{l}\text { Wanalertlak et } \\
\text { al. [37] }\end{array}$ & Global path cache & $\begin{array}{l}\text { Delay, prediction of next } \\
\text { AP, no. of cache }\end{array}$ & $\begin{array}{l}\checkmark \text { Reduced time to find } \\
\text { AP }\end{array}$ & $\begin{array}{l}\text { x Authentication delay less } \\
\text { emphasized, problem of MAC } \\
\text { contention not considered. }\end{array}$ \\
\hline Khan [38] & $\begin{array}{l}\text { Localized } \\
\text { authentication } \\
\text { technique }\end{array}$ & Authentication latency & $\begin{array}{l}\checkmark \text { Enhanced performance } \\
\text { of authentication }\end{array}$ & $\begin{array}{l}x \text { Less evidences of outcomes and } \\
\text { data analysis. }\end{array}$ \\
\hline $\begin{array}{lll}\text { Priya } & \text { et } & \text { al. } \\
{[39]} & & \end{array}$ & $\begin{array}{l}\text { Elgamal based } \\
\text { authentication }\end{array}$ & Throughput & $\begin{array}{l}\checkmark \text { Resistive against DoS } \\
\text { attack }\end{array}$ & $\begin{array}{l}x \text { Improvement of authentication } \\
\text { delay not discussed. }\end{array}$ \\
\hline $\begin{array}{lll}\text { Idrissi et al. } \\
\text { [40] }\end{array}$ & 3G-WLAN & $\begin{array}{l}\text { Bandwidth, signaling } \\
\text { cost, authentication delay }\end{array}$ & $\begin{array}{l}\checkmark \quad \text { Highly resistance } \\
\text { against replay attack }\end{array}$ & $\begin{array}{lrl}x & \text { Not } & \text { applicable for dense } \\
\text { network. } & & \end{array}$ \\
\hline Moon [41] & $\begin{array}{l}\text { 3G-WLAN-IMS } \\
\text { registration method }\end{array}$ & Delay, arrival rate & $\checkmark$ Enhanced SIP & x Outcomes not benchmarked. \\
\hline \multicolumn{3}{|c|}{$\begin{array}{l}\text { 5. STUDIES ON WLAN AND CDMA } \\
\text { Most recently, there has been increasing attention towards } \\
\text { understanding the viability of performing an efficient handoff } \\
\text { mechanism for WLAN and CDMA cellular network. In this } \\
\text { regards, it should be known that the principle of handoff only } \\
\text { occurs during the cases of i) mobile upwards, ii) mobile }\end{array}$} & \multicolumn{2}{|c|}{$\begin{array}{l}\text { network performance. Although previous sections have } \\
\text { highlighted some studies focusing on vertical handoff } \\
\text { mechanism, but the discussion was mainly carried out to } \\
\text { highlight vertical handoff effectiveness and not much on the } \\
\text { case studies on heterogeneity. Hence, we will look into some } \\
\text { of the studies performed till date on WLAN and CDMA. }\end{array}$} \\
\hline
\end{tabular}
downwards, and iii) mobile through. Mobile upwards takes place when the mobile host moves from CDMA network (outside of WLAN) to WLAN network. Mobile download takes place when the mobile host moves from WLAN to other network that is connected to CDMA network. Mobile through takes place when any one of the available network is selected for media selection layer. Performing handoff mechanism for the CDMA networks as well as WLAN is never an easy task owing to their differences in the network entities. Usually, WLAN is used for encapsulating the hotspot zones with maximized data rate and minimized cost. The transmission area of CDMA is quite bigger than WLAN that offers network connectivity in minimized data rate and maximized cost. Hence, this is the significant tradeoff in WLAN and CDMA

The study conducted by Narisetti et al. [42] has presented a design of a vertical handoff framework considering WLAN and CDMA networks. The outcome of the study shows better mobility management and significantly minimizes the delay during vertical handoff. A similar type of the study was also presented by Chou et al., that used intelligent agents for i) load balancing and ii) authentication process. The study has considered pre-authentication along with SIM based validation mechanism for the UMTS users. The outcome of the study was done considering i) blocking ratio, ii) packet loss ratio, iii) proportion for new call blocking, iv) ratio of call interruption, v) overhead on channel capacity. The outcome of this study using intelligent agent was compared with techniques without mobile agents and convention mobile 
agent to find that it offers better performance. Kim et al. [44] have presented an algorithm for selecting context-based network that depends on distance data, signal strength, and process of selection of network. The outcomes of the study show better blocking probability, packet dropping probability, and number of handoff. Agarwal and Kaur [45] have designed an algorithm for vertical handoff for WLAN and CDMA. The outcomes of the study were evaluated using throughput, handoff delay and were not benchmarked. Similar pattern of study was also carried out by Pande and Mhala [46]. The simulation study was done in NS2 considering the performance parameters as network delay, time, throughput. However, the outcomes were not found to be benchmarked. The next section will discuss about the significant research gap that has been witnessed in the existing contribution toward vertical handoff mechanism.

\section{RESEARCH GAP}

From the viewpoint of the existing studies towards vertical handoff mechanism in heterogeneous network, it can be said that all the existing studies have their potential merit point as well as limitation. Table 1 and Table 2 highlights the inference of the trends of the work being witnessed for enhancing handoff performance exclusively taking the case studies of heterogeneous network. The research gaps explored in the existing studies are as follows:

\subsection{Less Emphasis to System Requirements}

Studies considering WLAN and $3 \mathrm{G}$ cellular services usually consider to hide the authentication delay using cellular services. A good example to understand this is if the WLAN network is encapsulated by the $3 \mathrm{G}$ network while a mobile terminal performs handoff from $3 \mathrm{G}$ to $\mathrm{Wi}-\mathrm{Fi}$, it is seen that mobile terminal has the capability to retain the $3 \mathrm{G}$ connection until the authentication process of $\mathrm{Wi}-\mathrm{Fi}$ is accomplished. However, these sorts of approach are accompanied with pitfalls. The first pitfall is that such techniques cannot ensure the availability of WLAN to be always covered in 3G network. Second pitfall factor is, such techniques are less applicable to WLAN as it supports multiple Access Stations. Hence, seamless authentication delay is major problem in WLAN and 3G cellular network, as owing to multiple AS, authentication delay is more.

\subsection{Less efficient mechanism of problem formulation}

Majority of the existing studies towards heterogeneous networks and its associated handoff mechanism are formulated considering large number of machines (or computing devices) and network parameters. From algorithm implementation viewpoint, such consideration of large number of research variable will significantly affect the algorithm performance. Hence, there is a need to evolve up with a design tactics that can formulate a precise parameter for performing decision operation of performing handoff mechanism.

\subsection{Improper Algorithm Consideration}

It was also seen that certain algorithms were designed using evolutionary techniques like neural network. Adoption of such techniques is good enough for offline analysis but never for online analysis. Training algorithm offers preciseness only with the availability of data, which cannot be ensured in online case studies of handoff mechanism.

\subsection{Less Emphasis on Authentication factor}

In majority of the existing studies, the term authentication is found to posses dual meaning, where both the meanings are quite valid viz. authentication using networking protocol during handoff and authentication using security protocols during handoff mechanism. Interesting, all the studies are significantly found to ignore the significance of security or cryptographic implementation for contributing fast authentication standards. Less work is done towards implementing new and robust cryptographic standards over heterogeneous network to ensure a fail-proof authentication system. Although there are certain studies using cryptographic technique, but those studies were found not to discuss about the effectiveness of the cryptographic techniques to reduce authentication delays in large scale handoff system with variables like mobility of the users.

\subsection{Less Benchmarked Studies}

Majority of the existing studies towards vertical handoff mechanism were discussed in the research papers. However, very few benchmarked outcomes were observed. Although some of the studies have explicitly claimed that their outcomes were better but there is no mean to prove it with respect to other existing studies.

\subsection{Less Improvement in WLAN-CDMA}

The studies towards WLAN and CDMA are witnessed with positive outcomes as there are less number of switches between CDMA and WLAN network. Although, such outcomes are in compliance with real-time requirement, it seriously posses limitations. Imprecise selection of research variables in such studies will lead to unwise resource consumption that will directly affect the performance of the networking devices which is incorporated with such algorithms.

\section{CONCLUSION}

Repeated discussion of theory is avoided in this manuscript as in existing system there is availability of various research paper highlighting the same over internet. The prime attempt made in this paper is to highlight some of the significant studies undertaken in vertical handoff schemes in heterogeneous wireless network and extract research gap. Hence, it can be seen from the paper that there is a need of performing investigation towards designing an effective authentication protocol. This paper identified the issues mainly in WLAN-CDMA; future work will be in similar direction. The prime objective of future work will be to evolve with an improved vertical handoff algorithm by considering multiple challenging system and network parameters in order to reduce decision delay. The future work will also consider a mechanism to select the Access Point based on distance, power consumption, cost and bandwidth by reducing the delay on multiple test-scenarios of mobility.

\section{REFERENCES}

[1] Wang, Y., Ma, J.2014. Mobile Social Networking and Computing: A Multidisciplinary Integrated Perspective. Computers, CRC Press, pp. 414

[2] Sauter, M.2010.From GSM to LTE: An Introduction to Mobile Networks and Mobile Broadband.Communication Systems for the Mobile Information Society, pp. 480 
[3] Hossain, E.2008. Heterogeneous Wireless Access Networks: Architectures and Protocols (Google eBook). Springer Science \& Business Media, pp. 8

[4] Saily, M., Sébire, G., Riddington, E.2011. GSM/EDGE: Evolution and Performance (Google eBook). John Wiley \& Sons, pp. 504

[5] Cox, C.2012. An Introduction to LTE: LTE, LTEAdvanced, SAE and 4G Mobile Communications (Google eBook). John Wiley \& Sons, Technology \& Engineering, pp. 352

[6] Ismail, K.2012. Contemporary Challenges and Solutions for Mobile and Multimedia Technologies (Google eBook). IGI Global, Technology \& Engineering, pp. 399

[7] Makki, K., Pissinou, N., Makki, S. K., Park, E.K.2012. Mobile and Wireless Internet: Protocols, Algorithms and Systems (Google eBook). Springer Science \& Business Media, pp. 391

[8] Stüber, G.L.2013. Principles of Mobile Communication (Google eBook). Springer Science \& Business Media, pp. 665

[9] Misra, I. S.2013. Wireless Communications and Networks: $3 \mathrm{G}$ and Beyond. McGraw Hill Education (India) Pvt Ltd, pp. 551

[10] Mukherjee, A., Bandyopadhyay, S., Saha, D.2003. Location Management and Routing in Mobile Wireless Networks. Artech House, Technology \& Engineering, pp. 213

[11] Holtzman, J. M.2012. Wireless Information Networks: Architecture, Resource Management, and Mobile Data (Google eBook). Springer Science \& Business Media, pp. 404

[12] Li, J., Wu, X., Laroia, R.2013. OFDMA Mobile Broadband Communications: A Systems Approach. Cambridge University, pp. 519

[13] Zeng, Q-A., and Agrawal, D.P.2002. Handoff in Wireless Mobile Networks. Handbook of wireless networks and mobile computing

[14] Hemavathi, S Akhila. 2015. A Survey on Delay in Vertical Handoff in Heterogeneous Wireless Networks. International Journal of Advanced Information Science and Technology (IJAIST), ISSN: 2319:2682

[15] Rawat, B., Danda.2013. Security, Privacy, Trust, and Resource Management in Mobile and Wireless Communications (Google eBook). IGI Global, pp. 577

[16] Hong, Y.-W. P., Huang, W-J., Kuo, C.-C. J.2013. A Reinforcement Sensor Embedded Vertical Handoff Controller for Vehicular Heterogeneous Wireless Networks. Open Access Sensors, pp. 15026-15047

[17] Zahran, A.H., and Liang, B.2006. ALIVE-HO: Adaptive lifetime vertical handoff for heterogeneous wireless networks. Technical Report, University of Toronto

[18] Mohanty, S., and Akyildiz, I. F.2006. A cross-layer (Layer $2+3$ ) handover management protocol for nextgeneration wireless systems. IEEE Trans. Mobile Computing, Vol. 5, pp. 1347-1360
[19] Yan, X., Mani, N.N., and Ekercio glu, Y.A.S.2008. A Traveling Distance Prediction Based Method to minimize Unnecessary Handovers from Cellular Networks to WLANs. IEEE communication letters, Vol. 12, pp. 14-16

[20] Choi, H-H., and Cho, D-H.2005.TAKEOVER: A New Vertical Handover Concept for Next-Generation Heterogeneous Networks. In Vehicular Technology Conference, VTC-Spring, IEEE 61st, Vol. 4, pp. 22252229

[21] Zahran, A.H., Liang, B., and Saleh, A.2006. Signal threshold adaptation for vertical handoff in heterogeneous wireless networks. Mobile Networks and Applications, Vol. 11, No. 4, pp.625-640

[22] Liu, M., Li, Z-C., Guo, X-B., Dutkiewicz, E., Zhang, DK.2006.Performance evaluation of vertical handoff decision algorithms in heterogeneous wireless networks.University of Wollongong Research Online, pp. 1-5

[23] Navarro, E.S., Wong, V.W., and Lin, Y.2007. A vertical handoff decision algorithm for heterogeneous wireless networks. In Wireless Communications and Networking Conference, WCNC, IEEE, pp. 3199-3204

[24] Arun, E., Moni, R.S.2009. Handoff in Heterogeneous wireless networks by Adjusting the Transmission Power [RSS]/Rate. International Journal of Recent Trends in Engineering, Vol 2, No. 4

[25] Gondara, M. K., and Kadam, S.2011. Requirements of Vertical Handoff Mechanism in 4G Wireless Networks. International Journal of Wireless \& Mobile Networks (IJWMN) Vol. 3, No. 2

[26] Sharna, S., and Murshed, M.2011. Performance improvement of vertical handoff algorithms for QoS support over heterogeneous wireless networks. In Proceedings of the Thirty-Fourth Australasian Computer Science Conference-Vol. 113, pp. 17-24

[27] Bijwe, A., Dethe, C.G.2015. RSS based Vertical Handoff algorithms for Heterogeneous wireless networks - A Review. International Journal of Advanced Computer Science and Applications, Special Issue on Wireless \& Mobile Networks, pp. 62-67

[28] Nithyanandan, L., and Parthiban, I.2012. Vertical Handoff in Wlan-WIMAX-LTE Heterogeneous Networks through Gateway Relocation. International Journal of Wireless \& Mobile Networks (IJWMN) Vol. 4, No. 4

[29] Kadhim, D. J.2012. A New Approach of Vertical Handoff in the Heterogeneous Wireless Networks., International Journal of Computer Applications, Vol. 57, No.9

[30] Kunarak, S., and Suleesathira, R.2013. Algorithmic vertical handoff decision and merit network selection across heterogeneous wireless networks.WSEAS Transactions on Communications, Vol. 12, No. 1, pp. 113

[31] Shen, Y., Xi, N., Peii, Q., and Mai, J.2014. The QoSEnsured Vertical Handoff Decision in Heterogeneous 
Wireless Networks. Journal of Information Science and Engineering, Vol. 30, pp. 875-893

[32] Huang, S., Hao, C-H., and Zhang, W.2006. SAP: seamless authentication protocol for vertical handoff in heterogeneous wireless networks. In Proceedings of the 3rd international conference on Quality of service in heterogeneous wired/wireless networks, pp. 32

[33] Dutta, A., Famolari, D., Das, S., Ohba, Y., Fajardo, V., Taniuchi, K., Lopez, R., and Schulzrinne, H.2008. Media-independent pre-authentication supporting secure interdomain handover optimization. Wireless Communications, IEEE, Vol. 15, No. 2, pp.55-64

[34] Ahmed, M., and Murtaza, A.2010. Decision algorithm and procedure for fast handover between $3 \mathrm{G}$ and WLAN

[35] Zahran, A.H., and Sreenan, C. J.2011. Extended Handover Keying and Modified IEEE 802.21 Resource Query Approach for Improving Vertical Handoff Performance. In New Technologies, Mobility and Security (NTMS), 24th IFIP International Conference on, pp. 1-7

[36] Faisal, M., Khan, M.N.2012. An enhanced Scheme for Reducing Vertical handover latency. International Journal of Advanced Computer Science and Applications, Vol. 3, No. 1

[37] Wanalertlak, W., Lee, B., Yu, C., Kim, M., Park, S-M., and Kim, W-T.2013. Scanless fast handoff technique based on global Path-Cache for WLANs. The Journal of Supercomputing, Vol. 66, No. 3, pp.1320-1349

[38] Khan, M. W.2013. Secure and Efficient Vertical Handover in Heterogeneous Wireless Networks. Int. J. Advanced Networking and Applications, Vol. 5, Issue. 2, pp. 1908-1922

[39] Priya, M. D., Bharathi, K. J., Valarmathi, M.L.2013. Fast and Secure Handover in IEEE 802.16e Networks.,
Journal of Global Research in Computer Science, Vol. 4, No. 4

[40] Idrissi, Y. E. H. E., Zahid, N., and Jedra, M.2014. A New Authentication Method for Vertical and Horizontal Handover in 3G-WLAN Interworking Architecture. Research Journal of Applied Sciences, Engineering and Technology, Vol. 7(2), pp. 329-342

[41] Moon, B.2014. Fast and Secure Session Mobility in IMSbased Vertical Handover Scenario. International Journal of Multimedia and Ubiquitous Engineering, Vol.9, No.9, pp. 171-188

[42] Narisetti, M.2006. Implementation of Vertical Handoff Algorithm between IEEE802.11 WLAN and CDMA Cellular Network. Georgia State University ScholarWorks@ Georgia State University

[43] Chou, L-D., Lai, W-C., Lin, C-H., Lin, Y-C., and Huang, C-MIN.2007. Seamless Handover in WLAN and Cellular Networks through Intelligent Agents.Journal of Information Science and Engineering, Vol. 23, pp. 10871101

[44] Kim, J-S., Serpedin, E., Shin, D-R., and Qaraqe, K.2008. Research Article Handoff Triggering and Network Selection Algorithms for Load-Balancing Handoff in CDMA-WLAN Integrated Networks. Journal onWireless Communications and Networking, Article ID 136939, pp. 14

[45] Agarwal, R., and Kaur, I.2012. Comparative Analysis Of Vertical Handoff In IEEE 802.11 WLAN And CDMA Network. International Journal of Engineering Research and Applications, Vol. 2, Issue. 4, pp. 1122-1128.

[46] Pande, V. S., Mhala, N. N.2013. Implementation of Vertical Handoff Algorithm between IEEE 802.11 WLAN \& CDMA Cellular Network. IOSR Journal of Electronics and Communication Engineering (IOSRJECE), Vol. 6, Issue. 6, pp. 57-62 